\title{
The historical evolution and enforcement of competition law in Pakistan
}

\author{
Nishan E. Hyder Soomro*1 ${ }^{*}$ Asif Khan ${ }^{1}$ | Yongyeh Naglim Elizabeth ${ }^{1}$ | Alexandra Jane Davis ${ }^{2}$ \\ 1. School of Law and Economics, Zhengzhou University, Zhengzhou, China. \\ 2. Guanghua Law School, Zhejiang University, Hangzhou, China. \\ *Correspondence Emails: nishan_hyder@hotmail.com | nishanehydersoomro@gs.zzu.edu.cn
}

\begin{abstract}
The study aims to highlight competition law in various aspects and gives a detailed account of its origin over time by underscoring legislation's salient characteristics. The research attempts to feature its structure, power, and policies while identifying the challenges faced by the contemporary competition law in Pakistan. The study adopts qualitative data analysis. The research assessed regulatory agency's effectiveness as a principal authority to apply competition policies while preventing anticompetitive conduct. The research contents that many sustainability challenges are being faced by competition law in Pakistan and globalized transformation is one of the reasons behind it, thus it needs to be addressed. It is recommended that there should be an ability to attract professionals and judicial discourse that needs to be based upon sound economic rationale as per competition theory. However, competition law is supposed to prevent anti-competition rituals and practices by nurturing free and fair competition in the market. It promotes greater competition in the market by safeguarding customers against inaccurate means adopted by firms. Therefore, competition law is essential for regulating businesses by ensuring producer and consumer welfare. It ultimately promotes healthy growth of the economy and social justice if there is consistent enforcement of the law.
\end{abstract}

Article History

Received:

June 12, 2021

Revised:

July 12, 2021

Re-revised:

July 28, 2021

Accepted:

August 21, 2021

Published:

September 14, 2021

Keywords: Competition Commission of Pakistan, competition law, competition act, competition theory, international competition network, Pakistani regime, competition challenges.

How to Cite: Soomro, N. E. H., Khan, A., Elizabeth, Y. N., \& Davis, A. J. (2021). The historical evolution and enforcement of competition law in Pakistan. Liberal Arts and Social Sciences International Journal (LASSIJ), 5(2), 30-43. https://doi.org/10.47264/idea.lassij/5.2.3

Publisher's Note: IDEA PUBLISHERS (IDEA Journals Group) stands neutral with regard to the jurisdictional claims in the published maps and the institutional affiliations.

Copyright: (C) 2021 The Author(s), published by IDEA PUBLISHERS (IDEA Journals Group).

Licensing: This is an Open Access article published under the Creative Commons AttributionNonCommercial 4.0 International License (http://creativecommons.org/licenses/by-nc/4.0/) 


\section{Introduction}

The history of competition law in Pakistan started from 1970-2010. Parliament of Pakistan, on 23 September 2010, unanimously approved Competition Act 2010. A change duration adhered to for the Competition Bill 2009 in October when it existed to Pakistan National Assembly for legislative authorization as it dramatically relocated in the direction of a short-term stage to a long-term one Competition Act 2010 was developed for advertising a reasonable and also affordable economic climate that outright was an area for a whole business field, while shielding customers and also securing financial effectiveness as a result of the existence of anticompetitive methods and also perspectives. The title taken on by Competition Act 2010 shows the range and also purposes of the legislation due to the fact that it has a substantial application as well as is broader in range than the previous MRTPO 1970-2010 (Soomro \& Yuhui, 2021).

As stated by the Asian Development Bank is greater than a hundred territories with an ICN implementation based upon competitor's companies, is 189 states. The 56 states that are members of the Organization of Islamic Conference started pondering on issues related to Competition that the member states have confronted. The competition law has become global (Shaw. 2021). Over the last few decades, the world has promptly moved on; rather than using the old "ineffective" traditional diplomatic methods, the world is in favour of adopting "flexible" soft law framework "acts of international actors having a prescriptive content and non-binding effect" in reconstructing the international economic governance rule in position, since World War II concluded (Jones \& Sufrin, 2016).

In Pakistan, improving the well-being of the citizens and promoting sustainable economic development are pursued by the government, emphasizing the magnifying consumer's and producer's welfare and promoting and protecting the economy's Competition. To achieve these goals, all those barriers that can harm the Competition, like abuses of dominance, cartels, etc., must be eliminated to ensure that consumers' and producers' welfare is maximized (Boaz, 2009). At present, Pakistan's competition policy is protected by the Competition Act of 2010. Initially, in Pakistan, reforming the Competition's regime proceeded at quite a slow pace. By the end of 1990, some momentum was gained by 2005 when the Pakistan government asked for technical aid for designing a new competition law, including a policy framework for Pakistan from the World Bank. For this purpose, World Bank approached me so that researcher could aid in drafting different parts of the new competition law. Initially, the new competition law was promulgated as the Competition Ordinance of 2007. Still, sooner or later, it gained its constant position as the Competition Act of 2010 ("the Act"), a Parliament act opposing the impermanent legislation by the President. The study aims to investigate the origins of Competition law in Pakistan and its challenges (Darr, 2020).

\section{Literature review}

A plethora of literature has been produced on competition law in general; however, less scholarly work is done on competition law in Pakistan. According to Dhall (2019), competition law's globalization is more of a recent phenomenon than older strategies like typical polite initiatives to produce a global competitor's structure. Back in 1947, calls existed to introduce international rules related to Competition at the forum of the International Trade Organization via the Havana Charter. But neither any organization was established nor mentioned competition rules made by General Agreement on Tariffs and Trade. Fatima (2012) contended that the same thing happened in the 1950s when efforts were made towards internationalization 
of competition rules through the United Nation Economic and Social Council, in a similar way in the 1980s when using volunteer United Nation General Assembly Set of Multilaterally Agreed with Equitable Principles and also rules for Control of Restrictive trade Practices. However, according to Gerber (2020), hope existed for a very short time regarding the Working Group on Interaction between Trade and Competition Policy, in 2001 consisting of approval of the Doha Ministerial Declaration. The decision of Doha Work Program quit all the initiatives hereof in 2004. The situation was changed by the participation of regional and international organizations. Concerning this, the World Bank, International Monetary Fund.

United Nations Commission of Trade and Development, as well as the Organization of Economic Conference and Development, have actually been amongst one of the most famous companies. It has been argued by Joseph (2011), the WB and IMF have proven to be quite helpful, as in many cases, improvement or adoption was done by them since to gain access to financial resources, the condition states must abide by the competition laws. The OECD is principally active whenever it comes to providing technical capacity-building assistance to states, irrespective of whether they have adopted competition legislations or plan to in future, for example, China. UNCTAD also considers itself as an informal platform for the occurrence of discussions related to competition policy. Aside from publishing model competition law, recommending domestic legislation also offers technical regard assistance (ICDT, 2011).

It is said by Fiammetta (2010), the Competition Act, 2010 (CA' 10) is one of a kind law, which gave Competition Commission of Pakistan investigative and legal instruments as well as authorities to produce unrestricted Competition in every single area of monetary and commercial activity, increase monetary productivity, besides ensuring that end users are protected from exploitative actions. This Act applies to actions in Pakistan; nonetheless, their ownership being private or public, as well as the matters that might affect Competition in Pakistan. Being an enabling law, it organizes procedures about reviewing mergers and acquisitions, investigations, imposing penalties, granting leniency, including other necessary aspects of law enforcement (Einer \& Damien, 2011). The regulation protects against scenarios that often tend to misshape, decrease or remove Competition. like activities of abusing market supremacy, arrangements limiting competition and also unethical advertising techniques.

In 2019, Ahmed Chaudhry and Ummad Mazhar published an article Political competition and economic policy: empirical evidence from Pakistan. They explained that the impact of national politics on a financial plan is not totally recognized. The obstacle to making certain political inclusiveness as well as financial success continues to be. Possibly, one means to achieve this purpose is by raising political competitors. This paper collects empirical proof from Pakistan, a nation with a checkered political background defined by episodes of rep, non-representative, as well as indirectly elected federal governments. Recently, the nation has actually seen progressive conditioning of autonomous regulations with financial progression. Concentrating on nine political elections held 1970-2015 the writers determine political competitors and approximate their effect on the financial plan. Unlike prominent perceptions concerning Pakistan's economic climate, they locate a favourable organization between the absence of political competitors and an inadequate financial plan. This post ended that why examines the web link between national politics and business economics, concentrating particularly on political competitors on financial plans. Both theoretically and also proof, political competitors are recorded to have a favourable impact on financial results. The underlying system is autonomous responsibility: If political celebrations stop working to supply, they are likely to be changed by their bodies politic in the following political elections. 
Does this partnership hold the pledge of financial success for young as well as unsteady creating nations? In Pakistan, a breakable autonomous arrangement integrated with an appealing economic climate and a background of altering political organizations give a perfect situation to evaluate effectiveness of this weblink in between political competition and financial plan. Both panel information (at the rural degree) and time-series information (at the nationwide degree) are utilized to examine the influence of political competitors on plan varying from 1970-2015, covering nine basic political elections. Our plan signs contain advancement expenses and also present expenses at the rural degree and also present expenses, advancement expenses, health and wellness expenses, indirect tax obligations and also power manufacturing capability at the nationwide degree (Chaudhry \& Mazhar, 2019).

Darr (2018) published an article named "Role of courts in enforcing competition laws: a comparative analysis of India and Pakistan" and explained that Establishing nations embrace contemporary competitors regulations based upon global plans for inspirations varying from obtaining worldwide authenticity to accomplishing residential financial objectives. While embracing such regulations gives some authenticity to the competitors programs of these nations, it does not immediately convert right into the awareness of their financial objectives unless the regulations are likewise meaningfully implemented. Relative legislation literary works checked out in the light of growth business economics recommends that purposeful enforcement requires, to name a few points, efficient communication in between the embraced legislation and also the pre-existing lawful systems of the nations. In this write-up, I recognize feasible communications between competitors' legislation and pre-existing lawful systems in India and Pakistan and contrast the communications that happen in both nations. Even though Pakistan and India have virtually the same pre-existing lawful systems from British India and embraced comparable competitors' regulations within five years. However, the communications of these competitors' legislations with the pre-existing lawful systems in the nations are extremely various.

The study suggests that communications in a nation are significantly formed by the approach, systems, and lawful and political organizations whereby it embraces its competitors' regulation. The study shows that the sort of communication has a visible effect on the enforcement of competitors' legislation. In conclusion, the write-up ended that just how obtained competitors legislations communicate with the pre-existing lawful systems of the nations in which they are infused is a vital sign of the high quality of efficiency and without a doubt 'success' of these legislations the nations. Contrasting these communications in the Indian and Pakistani contexts recommends that the procedure where a nation obtains its competitors regulation, straight and indirectly, influence the quantum, nature, and result of communications in between the obtained competitors' regulations and the pre-existing lawful systems.

India uses a comprehensive, bottom-up, as well as participatory procedure for embracing its competitors legislation, is successful in establishing an extra effective communication in between the regulation as well as the pre-existing lawful system by integrating lawful residential factors to consider in the legislation as well as by completely involving political organizations to make sure that they are extra purchased guaranteeing that the organizations required for meaningfully carrying out the legislation are appropriately developed A nation like Pakistan that takes on the regulation via a unique as well as top-down procedure and also maintains lawful and also political establishments at a range in the fostering procedure finishes up with a legislation that drops brief of lawful residential demands as well as which stops working to harness assistance from political organizations as well as stakeholders for its 
purposeful execution. The nature and impact of these communications are connected to and differ with the more comprehensive competitor's application context of the nation and, for that reason, to the fostering procedure that develops this context.

It shows that those results of these communications might be handled and also typically helpful in a nation, which, like India, develops a working competitor's system as well as where a hurt individual can conjure up the constitutional territory of the courts or come close to the competitor's system for remedy of their complaints. Moreover, in nations such as Pakistan, which fall short of developing or preserving competitors' systems, these communications have the power to bewilder and annoy the execution of the competitors' legislations. While the fostering procedure might have formed the communications and their results, it does not stop the nations, as soon as they comprehend the preventing elements, from recharging their application trajectories and meaningfully implementing the competitors' regulations. In nations like Pakistan, it is still unclosed to the organizations to take possession of the legislation and also to reduce the effect of their earlier exemption: For the judiciary, this suggests removing the stockpile of competitors issues pending before the courts, as well as for the Parliament and also the federal government, it suggests devoting themselves to keep a competitor's system (Darr, 2018).

Wilson (2010) published an article titled "At the crossroads: Making competition law effective in Pakistan". That write-up went over the competitor's routine in Pakistan as developed by the Monopolies and MRTPO 1970; the business framework of MCA, the implementing body of the MRTPO; aspects hampering efficient enforcement of MRTPO, as well as factors of an efficient competitor's company.3 Since the magazine of my last item, the competitor's program in Pakistan has undergone huge modifications. In 2007, brand-new competitors' regulation was established, and also a brand-new enforcement company, the Competition Commission of Pakistan, was developed. The Commission has carefully implemented the legislation, separated some cartels, penalized leading gamers for abusing their market settings, removed over 200 merging's, and functioned to produce recognition of the brand-new competitor's regimen.

Ultimately, this short article ended that This paper had made some suggestions to enhance the performance of the organization: (i) that the variety of Commission participants be repaired at 5, and also the capability of the Federal Government to enhance or reduce at will be constricted; (ii) the regard to the participants be boosted to 5 years, and also participants be qualified to be elected for two terms just; (iii) judicial choices are made by the complete Commission, as well as must-do without hearing situations with a single-member bench; (iv) participants must be assigned in a clear, affordable and also strenuous fashion; and also (v) competitors regulation need to be imperatively provided in the LL.B. educational program. The Act helps the Commission by enforcing a favourable responsibility to examine the Act and make ideal suggestions to change it. 105 The Commission needs to regularly analyse the institutional setups to create an outstanding design for its sophisticated physics (Wilson, 2010).

\section{Research methodology}

The research work is considered an academic process done by a researcher to determine the impediments in the topic under study for a specific field. This is one of the important parts of the whole research. Thus, research methodology is a philosophical framework through which any examination or research is conducted or can also be called a foundation of any research. There is a need for an organized and regular research process having a well-established part of 
refining the problem statement as described and achieving the research objectives and aim through a proper analysis of the data collected based upon the topic of the research. The researcher kept in mind that data should be compiled by keeping the research objectives in mind and should be per the natural outcome of the research. The whole path of conducting accurate research is based upon the research methodology. It can be described as a relationship established by those studies or observations and other information sources or settings that you decide to utilize, the process or methods used to make sense of the collected data. This research methodology is developed for a specific topic to find out the problems and their suggested solutions, which are used in this research consisting of mainly the review of primary and secondary sources telling the origin of competition law in Pakistan while focusing on challenges that are being faced by this law.

\subsection{Research design}

The nature of the research study describes the study layout utilized to perform the study. A qualitative approach was utilized for performing this research study. A qualitative study style has actually been utilized while considering it better to this certain research. As pointed out over, qualitative research study is performed, which would certainly assist the scientist fulfil the objectives and also purposes of the existing research. It has actually usually been taken into consideration helpful for social scientific research when it involves qualitative study. Considering that it plays an exceptionally substantial duty in using a thorough summary of the subject and also the study, numerous advantages. It does not restrict the study's range and also the individuals' feedbacks.

\subsection{Data collection}

The research has divided these qualitative research sources into two parts: Primary and Secondary Sources. Both primary and secondary sources collected data for this research. The research study uses main records and also various other certifications to perform the study. The research study behind utilizing key resources is they aid offer direct or straight proof pertaining to a thing, occasion, individual or job. They assist offer the initial products that offer a structure to the researcher's job while making it possible for various other researcher to recognize extra very closely regarding the under-examination subject.

The researcher utilizes secondary resources several times to accomplish even more research study. To place it simply, it can be competed that information is gathered by somebody else than a researcher; nevertheless, this information is utilized by the research study for satisfying its research study's goals. Today research intended to evaluate as well as completely examined various publications, journals, paper magazines, as well as academic short articles. Additional information was accumulated from press resources. With the logical strategy with relative evaluation, the factor behind making use of secondary sources is that scientist investigates by examining additional information by using details Researchers take advantage of the evaluation of second information to try any type of research study inquiry to be responded to. A different viewpoint is offered by additional information on a previous research's initial concern. It plays a vital function in gathering key information, even more especially with second information's assistance. The additional information made it possible for the researcher to highlight shortages as well as voids and also added info that required to be accumulated. The additional information intended to enhance the trouble's understanding in the present research. Additional information offered a basis to make any type of contrast of accumulated information. 


\section{Origin of competition law in Pakistan}

In 1970, Pakistan's first competitor's legislation of Pakistan was established by the promote of the Monopolies and Restrictive Trade Practices MRTPO 1970. Because the financial power was focused within family-based service teams, this resulted in the fostering of regulations that intended to stop 'excessive focus of financial power, unreasonably limiting profession techniques and also the development of unreasonable syndicate power.' From arrangements, the verdict was established that MRTPO 1970 offered to separate solitary or domestic property of companies and presented privatization of possession, placing restrictions on merging and purchases in the nation (Zoghbi, 2007).

The Monopoly Control Authority (MCA) was formed for supervising this implementation (Government of Pakistan, 2001). Although the MRTPO 1970 was ambitious, it was not as effective because of various political, economic, and legal considerations. Soon after its promulgation, all main industries were nationalized by the government. An exemption was given to enterprises owned by the state, and MRTPO 1970 application was not applicable until the nineties process of privatization started. The Independent existence of MCA was lost, while the MRTPO 1970 in 1981 was included in Pakistan's Corporate Law Authority and was pushed further on the backburner. On paper, MRTPO 1970 still existed, but its significance was lost compared to the main mission taken by the Corporate Law Authority, i.e., regulation of corporate affairs and registration of companies. In 1994, when the independence of MCA was regained, the desire to draw in exclusive as well as international financial investment for the federal government developed competitors' regulation applications much less advantageous under competition law. Since the economic realities were changing, MCA realized itself to be quite powerless: neither had it had any power to form pre-merger notification compulsory, nor it could go against any enterprises owned by the state or do anything more than smacking a wrongdoer on the wrist (Government of Pakistan, 2010).

\section{Reforming competition law in Pakistan}

Pakistan initiated reforming its competition law when the liberalization and privatization regime started in the nineties. In 1993, calls to overhaul the competition regime were made, but the government only took it seriously when the soft legislation structure of different international organizations was considered (The Competition Ordinance, 2007). The government turned to $\mathrm{WB}$ and IMF for technical and financial assistance to restructure the economy of Pakistan. Pakistan since 1955, got aid from IMF resources via three Standby Credit Facilities (1995-1997, 2000-2001, 37 2008-2011, 38), one three-year combined Enhanced Structural Adjustment Facility/Extended Fund Facility (1997-2000), and one three-year Poverty Reduction and Growth Facility (2001-2004). For getting these centres, in the last years, three nationwide methods were prepared by PRSP: ad Interim PRSP-41 in 2001, in 2003 the PRSP-I, and also in 2009 PRSP-II (The Competition Ordinance, 2010). The energetic participation of many worldwide companies brought about the prep work of these documents. While thinking about keeping track of reforms in PRSP-I, prepares to change the MCA while taking on a brand-new competitors legislation made by the federal government.

While the Monopoly Control Authority had urged restructuring by utilizing OECD and German versions in 2001 and 1993, specifically, it was these very first circumstances that this problem was taken utterly by the federal government. Pakistan's need to boost its monetary frameworks and acquire IMF as well as WB financing and participation was the driving pressure called for 
to additionally this problem on the federal government's schedule (Hussain, 2010). Assistance was supplied by many variables advertising the point of view that the worldwide companies accomplished a vital part in the improvement treatment. In 2005, the federal government asked for WB's technological support for the growth of brand-new competitors' legislation in addition to its plan structure. Therefore, WB entailed a Brussels-based law practice for mapping out predicted legislation. The company mapped out a unique regulation, adhering to the EU design, a 'structure it was most aware of.' Legislation being as necessary modified using the federal government's exec department, which escaped the nation's legislature and also promoted it as the ordinance for Competition 2007 (Carbon Monoxide, 2007).

The CO 2007 significantly preserved all-encompassing EU language and legal features. Section 03 and 04 are two of the four substantive provisions involving exploitation of dominance and forbidden agreements, strikingly resembled article 101 and 103 of the treaty on the functioning of the European union, obvious on reading. In, 2009 when seeking new funding facility progress on the reformation of competition law was reported to the international organization in PRSP-II53 (CO, 2007). The importance given by government to this issue can be estimated by the fact that in PRSP-II, the term 'competition' was mentioned thirty times compared to economy several. The emphasis of Carbon Monoxide 2007, in addition to the very best techniques as well as international fads, was upon boosting customer well-being as well as securing Competition while banning four groups of anti-competitive habits: collusive contracts, misuse of prominence, advertising and marketing methods that are misleading, as well as specific procurement and also merging's (Nielson, 2018). There was an altered point of view upon the reasoning behind competitor's regulation. It showed up clear and concept to suppress syndicates for the circulation of a wide range. They transformed it into the concept of advertising Competition for financial development and also effectiveness (Dibadj, 2010).

The Competition Commission of Pakistan, under Competition Ordinance 2007, was empowered and mandated for three fundamental functions for protecting and promoting competition. First, the government authorized it in terms of undertaking law-enforcement actions while investigating substantive provisions possible violations; to come up with remedial measures for restoring Competition wherever they found violations by imposing substantial penalties on those who violate. Second, researching the competitiveness of the economy's various sectors was mandatory (Dabbah, 2010). Third, empowerment was also given to it by increasing awareness regarding Competition among stakeholders while suggesting policy and legislative reviews to present the government. For carrying out such purpose, powers were given to the Competition Commission of Pakistan to collect information from different sources, such as conducting inspections, impound evidence, documentary evidence, record testimony, request assistance from the public and other agencies, exercise broad powers, give leniency, and penalties. Competition Commission of Pakistan decisions were made effectively appealable before the country's Supreme Court directly. Thus, the brandnew legislation did not just develop a totally brand-new modern program that was rather comparable to ones that were discovered in a sophisticated lawful territory, according to worldwide finest techniques and also patterns, however likewise considerably equipped it while implementing the legislation.

\section{Challenges in the context of new competition regime}

In content the introduction of modern competition law in Pakistan, it can be seen that Pakistan is still facing many challenges. This first challenge is being faced by the country, creating this 
regime's acceptability in the country. There are some other challenges as well. The country has adopted the law due to economic and political demands (Dabbah, 2010). Numerous economic sectors have contributed to these big challenges. The state controls some because of nationalization and mixed planned-market economic policies; however, the present study investigates enforcement, political acceptance, financial autonomy, and capacity building.

\subsection{Political acceptance in Pakistan}

The parliament of the country received no official legislative discussion, still the country introduced CO 2007. As notification earlier, the government promulgated current competition law as an Ordinance on 03 October 2007; it was regarded as a temporary legislative instrument. Under the 1973 Constitution of Pakistan, parliamentary approval is needed for all ordinances within 120 days. In 1999, Gen. Pervaiz Musharraf proclaimed emergency and issued Provisional Constitutional Order (PCO). On 03 November 2007, permanency was given by PCO, among other things, purportedly to each legal instrument that President took and issued, which also included CO 2007. It can be said that it wasn't presented ever before in the country's parliament (PCO, 2007). The PCO was endorsed by the sitting parliament while enduring a resolution. Still, it did not pass an amendment to Constitution for condoning the actions of the President along with legal instruments. Thus, it can be contended that this new competition law faced its acceptability test as a challenge in Pakistan when Competition Ordinance 2007's permanent status was withdrawn because of the nullification of PCO and emergency by the country's Supreme Court. The law's future was in the doldrums (Competition Policy Report, 2007). However, an opportunity was provided by this uncertainty at the same time to political parties for debating this law for the first time in the country's history.

When this debate took place, the law was reintroduced by the democratic government as temporary legislation in the form of Competition Ordinance 2009 and Competition Ordinance 2010 to stop unhealthy competition in the market (Daudpota, 2013). It faced opposition from big businesses due to their interests; the Competition Commission of Pakistan successfully defended the law at hearings. The draft law was approved unanimously by a parliamentary committee. It was passed as Competition Act 2010. The establishment of Competition Act 2010 can be thought about as an indication of residential initiatives to recommend a brand-new competitors standard by political and autonomous forces in Pakistan; it guaranteed Competition a substantial location in its financial plan. A lot of drama, argument and conversation over CA 2010 indicated that lawmakers better comprehended the reasoning for modern competitors' regulation. Some adjustments were included in Competition Act 2007. Also, it came to be CA 2010 and presented Competition Appellate Tribunal for listening to charms versus various choices of Competition Commission of Pakistan (Rahman, 2010). It assisted in enhancing the optimum fine for endeavours that had identified turnovers while reducing the optimum charge for tasks that had unascertained turnovers; along with this, it also removed the authority of the Competition Commission of Pakistan in regard to transferring penalties in its fund. Competition Act 2010 coincided with Competition Act 2007 besides the modifications pointed out over.

\subsection{Implementation}

One of the biggest challenges faced by any country in terms of competition law is sustainable and consistent enforcement. Since its inception, a significant amount of work has been done by the CCP, which covers all mandatory areas. By the end of October 2012, it complied 35 inquiry 
reports while issuing fifty-nine orders along with drafted 13 policy opinions and notes, undertaken 247 merger analyses, held five meetings and conferences, led eight sector studies, written two reports of "state of competition," by authoring a compliance code for the private sector (Landolt, 2006). The members are considered to be significant for an institution that barely has five years to exist. The Competition Commission of Pakistan targeted price soon after its inception, along with production fixing cartels that operate via different trade associations and links. They have, even though it's giving low-hanging fruits and plaguing the economy of Pakistan. These cartels have done little to hide their deceitful practices. The Competition Commission of Pakistan has determined partnership in the past five years in the economic situation's many fields: book-keeping, financial, safety and securities, dredging, concrete, hemp bags, chicken, delivery, sugar, oil as well as gas, electrical power tools, edible oil, along with print media. Even so, the establishment has not been located timid sufficient to take and highlight situations of misuse of prominence.

Competition Commission of Pakistan keeps close to parity in between enforcement activity versus conspiracy theory as well as misuse of prominence. In the end of Oct 2012, orders were released by Competition Commission of Pakistan over greater than 12 circumstances where Competition Commission of Pakistan located rate discrimination, linking, as well as rejection or being rejected to deal. Competition Commission of Pakistan has lately introduced the intent to consist of anti-competitive technique in the general public purchase as well as a concession in its enforcement top precedence. While in the light of the substantial payment of these fields in the economic situation of Pakistan, the public purchase has alone totalled up to a matching of nationwide GDP' $25 \%$ at one, and also it can be claimed that selection has seemed rather reasonable. It has been approximated that suppressing negligence's that integrate collusive tendering and bidding process in public purchase will certainly contribute to conserving around 8 billion bucks yearly.

One of the most considerable cartels was discovered in 2011 in the production of hemp bags as well as electrical power devices industries. Also, they were appeared to be concentrated upon collusive bidding process (Dabbah, 2010). Formerly, the dredging and also sugar markets were discovered to be associated with a collusive bidding process. Hence, it can be claimed that enforcement selection appeared not just required however all-natural as well. For weaving a wide method, the Competition Commission of Pakistan intends to collaborate and cooperate with national regulatory authorities interested in the problem's public purchase. Competition Commission of Pakistan has routed a significant giving in owner in the giving ins market container incurable procedure to evaluate its profession exercise with consumers. The future will be substantial without a doubt exactly how effective the Competition Commission of Pakistan has actually remained regarding mainstreaming enforcement in the specified locations on a top priority basis.

\subsection{Financial sovereignty}

In 1996, the entire procedure began with the Pakistan Telecommunication Authority's facility to manage the nation's telecommunication sector in the industry following liberalization. The government developed the Securities and Pakistan Exchange Commission for controlling the safety and securities and company market fields. Various initiatives were made to control the power field, media industry, and oil field to offer oversight in downstream and centre markets. The concept behind developing various authorities was to take liberalized markets' guidelines far from the location as well as administration in the hands of particularized companies 
(Rahman, 2010). A crucial message was communicated by such companies that impartiality ought to be embraced to business' issues: it would certainly aid make policy specialists clear and apolitical.

To guarantee impartiality, monetary, procedure, and management, freedom was provided to such authorities in various fields. They were given the power to hire their team while making governing choices and producing their funds. They were enabled to impose charges as well as fines as parts of the law. For numerous factors, the non-reliance accurate of the taxpayer was essential. It made certain an operating setting without any political treatment. Yet, these companies were likewise enabled to supply unique income ranges to far better ability in the economic sector. Comparable freedom was offered to Competition Commission of Pakistan by Carbon Monoxide 2007. It was believed that Competition Commission of Pakistan would certainly play its function in imposing competitors' legislation throughout various markets. Also, it will certainly not have any tasks that create income.

Receiving revenue generated by these sectors was allowed to Competition Commission of Pakistan. In addition to this, taking grants from the government sector was also allowed with the permission letter from donors while retaining penalties recovered from those who violated. However, this scheme couldn't be effectively implemented and didn't work out well. Perhaps it was unforeseeable at declare, and despite many assurances from the side of the government, no agreement was made by any regulatory authority in terms of giving the Competition Commission of Pakistan its share in the generated revenue (Dabbah, 2010). The ability of Competition Commission of Pakistan was taken away by The CA 2010 in terms of receiving imposed penalties. It was considered a bona fide move in theory, which played its role in removing structural biases in the levy of fees and penalties. However, as an outcome, the Competition Commission of Pakistan was made dependent on allocations that the government made while putting its administrative and operational autonomy at risk.

\subsection{Enhance the capacity}

As legislation implementing establishment that applies any type of brand-new regulation, the requirement of the Competition Commission Pakistan to have trained specialists cannot be neglected. While taking into account the significance of this issue, the Competition Commission of Pakistan has actually revealed the ranks and files of its staff members. It has set up numerous training sessions, workshops, and meetings associated with its location of know-how. The competition Commission of Pakistan has actually utilized Capacity-building funds for educating its staff members in business economics, competitors' regulation, enforcement devices of competitors legislation, competitors campaigning for, in addition to computer system forensics. For such training, partnerships were made with various competitors' firms, like Turkish Competition Authority, and among the leading scholastic organizations such as Kings College of London and plan establishments like the Korea Policy Centre. These workouts made up a considerable brief medium-term approach for enhancing the staff members' capacity to undertake their jobs and also projects (Soomro, 2021). Additionally, a recent amendment to the service regulation of the Competition Commission of Pakistan has meant that a paid study leaves for the higher study for a year can be obtained by the employees who have served for at least three years in service. It can be said that such a policy would help to increase the Competition Commission of Pakistan employees' capacity greatly in the future. 


\section{Conclusion}

The study concludes that in Pakistan competition law faced many issues and challenges, and the successful application of soft law framework has been quite difficult, because it can be implemented effectively only through political acceptance and good enforcement strategy. However, commenting on the efficacy and sustainability of this law would be too early. Some challenges have been identified by this paper that would continue in terms of confronting this law in the future ahead, however, some recommendations given in this paper can be followed in order to make it successful and address those challenges. Usually, competitor's legislation is meant to stop anti competitors routines and methods by supporting cost-free and reasonable competitors in the marketplace. It inevitably advertises healthy and balanced development of the economic climate and also social justice. According to that, competitors' legislation system plays its function in securing competitors' procedures by requiring a durable, effective addition to independent competitors. As per competition theory, there should develop ability for attracting professionals along with judicial discourse based that need to be based upon sound economic rationale is important. There should be consistent enforcement of law.

\section{Declaration of conflict of interest}

The author(s) declared no potential conflicts of interest(s) with respect to the research, authorship, and/or publication of this article.

\section{Funding}

The author(s) received no financial support for the research, authorship and/or publication of this article.

\section{References}

Boaz, D. (Ed.). (2009). Cato handbook for policymakers. Cato Institute.

Chaudhry, A., \& Mazhar, U. (2019). Political competition and economic policy: Empirical evidence from Pakistan. Economics, 13(1). 1-27. https://doi.org/10.5018/economicsejournal.ja.2019-1

Competition (Merger Control) Regulations, 2007 vide order SRO 1188(I)/2007 (Islamabad, 20 November 2007) Reg. http://dartways.com/uploaded/laws/merger_control_regulations.pdf

Competition Law and Policy in Pakistan - IICJ. (n.d.). https://www.iicj.net/subscribersonly/09july/iicj6-competition-rahathassancompetitionauthority-pakistan.pdf

Competition Ordinance. (2007), PAK, Ordinance LII of 2007, published in the Gazette of Pakistan, extraordinary, Part 1 on 2 October 2007.

Competition Policy Report. (2007). A framework for a new competition policy and law: Pakistan. World Bank. https://documents.worldbank.org/en/publication/documentsreports/documentdetail/875361468283497835/pakistan-a-framework-for-a-newcompetition-policy-and-law

Dabbah, M. M. (2010). International and comparative competition law. Cambridge University. https://doi.org/10.1017/CBO9780511777745 
Darr, A. (2020). Cartels and the politics of competition law enforcement in Pakistan. SSRN Electronic Journal. https://doi.org/10.2139/ssrn.3726614

Darr, A. (2018). Role of courts in enforcing competition laws: A comparative analysis of India and Pakistan. Journal of Antitrust Enforcement, 7(1), 75-103. https://doi.org/10.1093/jaenfo/jny011

Daudpota, F. (2013). Anti-money laundering law of Pakistan an overview. SSRN Electronic Journal, 12(3), 22- 33. https://doi.org/10.2139/ssrn.2368483

Dhall, V. (2019). Competition law today: Concepts, issues, and the law in practice. Oxford University.

Dibadj, R. (2010). Conscious parallelism revisited. San Diego Law Review, 47, 589-640. https://digital.sandiego.edu/cgi/viewcontent.cgi?article=2677\&context=sdlr

Elhauge, E., \& Geradin, D. (2011). Global competition law and economics. Bloomsbury.

Fatima, S. (2012). Competition law in Pakistan: Brief history, aspirations and characteristics.

Commonwealth Law Bulletin, 38(1), 43-62.
https://doi.org/10.1080/03050718.2012.646734

Borgia, F. (2010, July). New governance mechanisms in international economic law: The role of soft law. In Society of International Economic Law (SIEL), Second Biennial Global Conference, University of Barcelona. https://papers.ssrn.com/sol3/papers.cfm?abstract id=1633984

Gerber, D. J. Competition law and antitrust: A global introduction and guide. In Competition Law and Antitrust (pp. 1-8). Oxford University. https://oxford.universitypressscholarship.com/view/10.1093/oso/9780198727477.00 1.0001/oso-9780198727477-chapter-1

Government of Pakistan. (2001). Interim poverty reduction and strategy paper. https://www.imf.org/External/NP/prsp/2001/pak/01/113001.pdf

Government of Pakistan. (2010). Poverty reduction and strategy paper - II (Country Report 10/183, IMF). https://www.imf.org/external/pubs/ft/scr/2010/cr10183.pdf

Hussain, D. (2010). Senate body to discuss competition bill. The Dawn.

ICDT. (2011). Report of the Istanbul conference on "needs assessment of the OIC member states in the field of competition law and policy. https://icdtoic.org/RS_67/Doc/Report_of_Istanbul_Conference.pdf

Jones, A., \& Sufrin, B. (2016). EU competition law: Text, cases, and materials. Oxford University.

Landolt, P. L. (2006). Modernised EC competition law in international arbitration. Kluwer Law International BV.

Nielson, A. L. (2018). The paradox of discretionary competition law. European Competition and Regulatory Law Review, 2, 156-165. https://doi.org/10.21552/core/2018/3/4

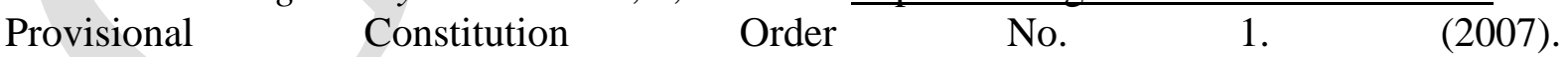
http://www.pakistani.org/pakistan/constitution/post_03nov07/pco_1_2007.html

Rahman, S. (2010). Competition law comes into force. Dawn https://www.dawn.com/news/855446/competition-law-comes-into-force

Shaw, J. (2021). Book review: A jurisprudence of the body. https://doi.org/10.1177\%2F09646639211007890

Soomro, N. H. (2021). Comparative study of competition law between China and Pakistan with special reference to the use of evidences submitted by companies to other legal proceedings. Journal of Politics and Law, 14, 96. https://heinonline.org/HOL/LandingPage?handle=hein.journals/jpola14\&div=27\&id $=$ \&page $=$ 
Soomro, N. E. H., \& Yuhui, W. (2021). Competition law in Pakistan and China: A comparative study. Journal of Politics and Law, 14(2). https://papers.ssrn.com/sol3/papers.cfm?abstract_id=3860348

The Competition Act $\quad$ No

(2010). http://www.na.gov.pk/uploads/documents/1306740606_319.pdf

The Competition Ordinance No XVI. (2010). https://wipolexres.wipo.int/edocs/lexdocs/laws/en/pk/pk072en.pdf

Wilson, J. (2010). Crossing the crossroads: Making competition law effective in Pakistan. Loy. U. Chi. Int'l L. Rev., 8, 105. https://heinonline.org/HOL/LandingPage?handle=hein.journals/intnlwrv8\&div=12 $\underline{\text { \&id}=\& \text { page }=}$

Zoghbi. (2007). Strategic priorities of competition and regulatory agencies in developing countries' draft paper. First Research Cycle of CUTS Competition, Regulation and Development Research Forum (CDRF) (2005-2007). https://www.circ.in/pdf/STRATEGIC\%20PRIORITIES\%200F\%20COMPETITIO N\%20AND\%20REGULATORY\%20AGENCIE.pdf 